
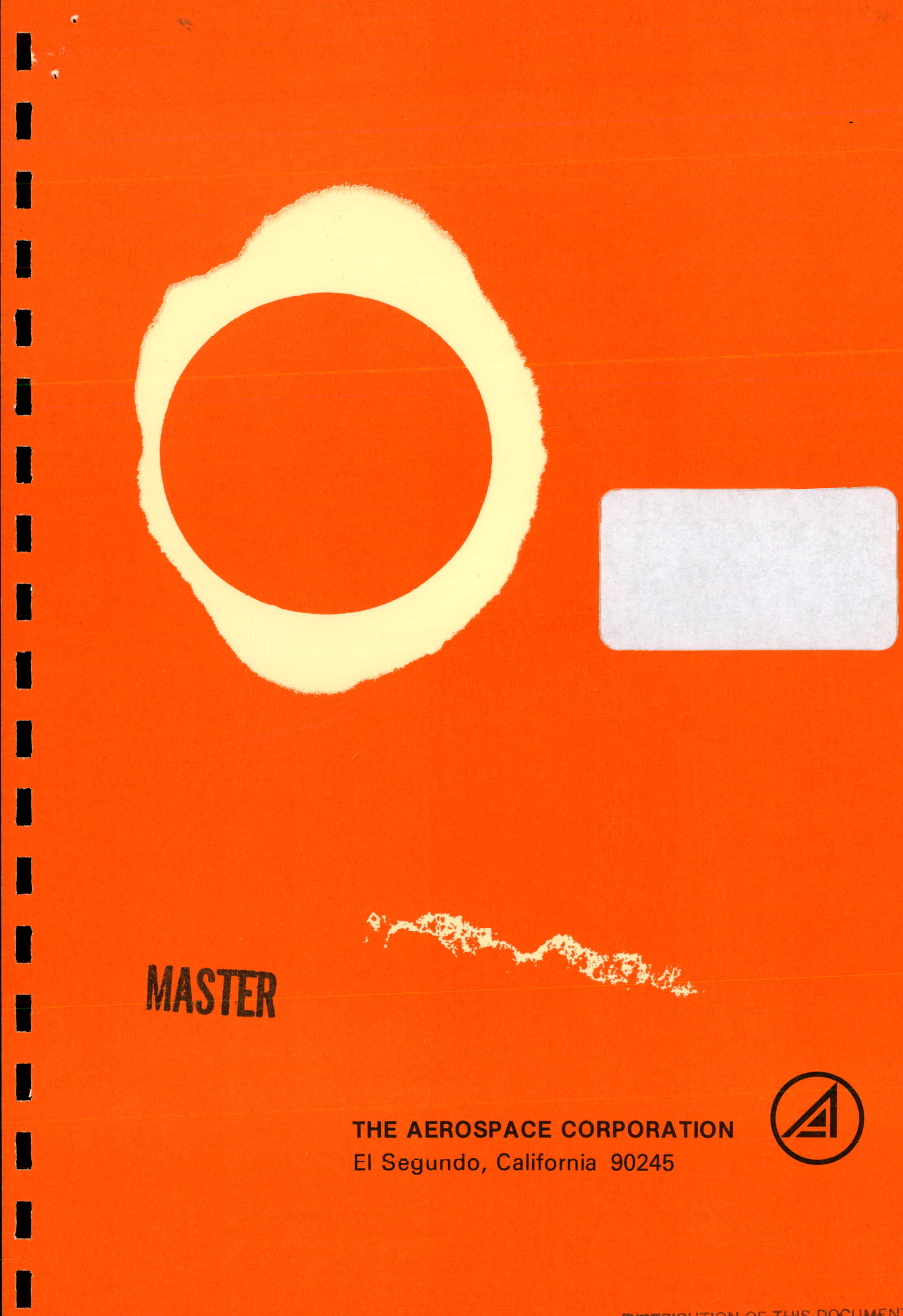

MASTER

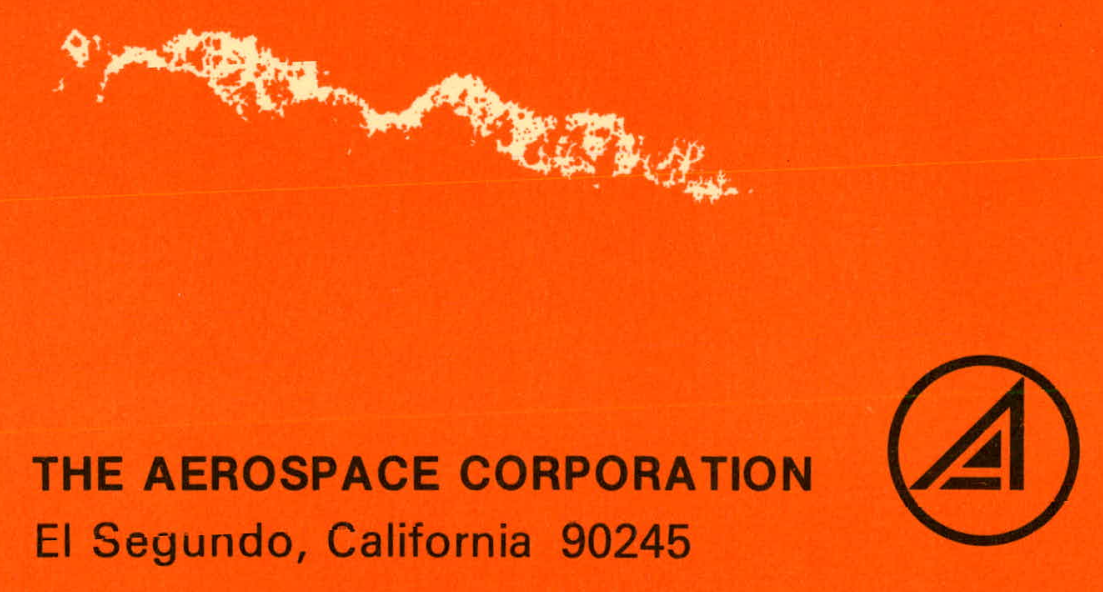

El Segundo, California 90245 


\section{DISCLAIMER}

This report was prepared as an account of work sponsored by an agency of the United States Government. Neither the United States Government nor any agency Thereof, nor any of their employees, makes any warranty, express or implied, or assumes any legal liability or responsibility for the accuracy, completeness, or usefulness of any information, apparatus, product, or process disclosed, or represents that its use would not infringe privately owned rights. Reference herein to any specific commercial product, process, or service by trade name, trademark, manufacturer, or otherwise does not necessarily constitute or imply its endorsement, recommendation, or favoring by the United States Government or any agency thereof. The views and opinions of authors expressed herein do not necessarily state or reflect those of the United States Government or any agency thereof. 


\section{DISCLAIMER}

Portions of this document may be illegible in electronic image products. Images are produced from the best available original document. 


\section{- -NOTICE--}

This report was prepared as an account of work sponsored by an agency of the United States Government. Neither the United States Government nor any agency thereof, nor any of their employees, makes any warranty, expressed or implied, or assumes any legal liability or responsibility for any third party's use or the results of such use of any information, apparatus, product or process disclosed in this report or represents that its use by such third party would not infringe privately owned rights. 


\title{
FORT HOOD SOLAR TOTAL ENERGY PROJECT
}

\section{Technical Support and Systems Integration}

\author{
Fort Hood Solar Total \\ Energy Project \\ Second Semiannual Report \\ 1 November 1978 - \\ 30 April 1979
}

I July 1979 Prepared by
The Aerospace Corporation
Energy \& Resources Division
El Segundo, California 90245

This report was prepared as an eccount of work sponsored by the United States Govemment. Neither the United States nor the United States Department of Energy, nor any of their employees, not any of their contractors, subcontractors, or their employees, makes any warranty, express or implied, or assumes, any legal liability or responsibility for the accuracy, completeness or usefulness of any information, apparatus, product of process disclosed, of represents that its use would not

process disclosed, or represents
infringe privately owned rights.

Prepared for

The U.S. Department of Energy

Albuquerque Operations Office

Under Contract DE-AC-04-78-ALO-4271 
This report presents a summary of tcchnical eupport of the Fort Hood Solar Total Energy Project conducted under the Department of Energy, Albuquerque Operations Office (DOE/ALO), Contract No. DE-AC04-78ALO4271. The time period for this contract is 1 May 1978 through 30 June 1979. This report is the Second Semiannual Report covering the second six months of progress on the contract.

The project support effort is being conducted by The Aerospace Corporation under the cognizance of Mr. D. K. Nowlin, Director of the Special Programs Division, and under the general direction of Mr. E. A. Walker, Senior Program Coordinator, at DOE/ALO.

This report was prepared by the Energy Projects Directorate of the Energy and Resources Division of The Aerospace Corporation, Mr. S. D. Huffman, General Manager. Dr. E. L. Katz, Director of the Energy Projects Directorate, is the Principal Investigator. Mr. J. T. Ator, Manager, Solar Thermal Projects, provides day-to-day management of project support activities. 
1.0 IN TRODUCTION 1

1. 1 Project History 1

1. 2 Project Organization 3

1. 3 Experiment Site 3

1. 4 Experiment Objectivco 6

2.0 PROJECT REDIRECTION 6

2. 1 Change in Energy Collection Approach 8

2. 2 Redistribution of Technical Support $\quad 10$

2. 3 Procurement Guidelines for Future Project Phases ' 10

3.0 SUPPORT ACTIVITIES DURING THE PERIOD 11

3. 1 Technical Review of Preliminary Design Final Report 11

3. 2. Technical Evaluation of Proposals 11

3. 3. Economic Analyses of STE-LSE Designs 11

3. 4. Shenandoah Project Support 16

3. 5 Project Planning Activities $\quad 16$

3. 6 Preparation of Phase III C Procurement Documentation 17

4.0 REFERENCES 


\subsection{INTRODUCTION}

\section{1 PROJECT HISTORY}

The Fort Hood Solar Total Energy Project began in May 1974 under National Science Foundation Grant No. AER74-17139AOl with an analysis of energy needs and available solar energy at Fort Hood and of potentially useful combinations of collection, conversion, and storage subsystems. A follow-on Phase II effort (see Figure 1-1) from April 1975 to September 1976 produced an initial conceptual system design and the selection of the 87000 troop housing complex as an energy load.

That initial design concept by American Technological University (ATU) incorporated a 220,000 $\mathrm{ft}^{2}$ distributed collector field designed to produce $530^{\circ} \mathrm{F}$ steam at $1000 \mathrm{psi}$ pressure for powering a $1.5 \mathrm{MWe}$ turbine generator. In early 1977 that design was determined to be unsatisfactory, and the Department of Energy (then ERDA) sponsored a design competition between TRW and Westinghouse to generate new approaches to meeting the solar experiment objectives at Fort Hood.

Westinghouse Advanced Energy Systems Division was the winner of that competition with a design calling for:a 150,000 $\mathrm{ft}^{2}$ parabolic trough collector field, paraffinic oil for a heat transfer medium, 250 kilowatts electrical output and 70 million Btu per day thermal output. That thermal output corresponds to the load presented by five specific buildings of the 87000 troop housing complex.

In March 1978 an eight-month Preliminary Design Phase began with ATU as prime contractor and Westinghouse as design subcontractor: Sub-tier contractors supporting Westinghouse were Heery and Heery, Inc. for site construction and interface design and Georgia Institute of Technology for collector system modeling and thermal storage facility design. That effort was concluded in November 1978 with a system design incorporating $125,000 \mathrm{ft}^{2}$ of parabolic trough collectors and providing a peak electrical output of 248 kilowatts. The annual thermal output is 17,304 million Btu and the gross electrical energy produced is $501,320 \mathrm{kwh}$. 


\section{PROJECT}

PHASE

I

II

III

\section{ACTIVIT Y}

Analysis of Applicability of Solar Thermal Systems to Military Installations*

Energy Loads and Insolation Data Collection, Collector

Test Loop Construction, and

Conceptual Design

Preliminary Design, Installation and Operation of Collector Test Module (Design task eliminated 4/77)

IILA

IIIB
Conceptual Design Competition

Preliminary Design
Westinghouse, TRW

A TU,

Westinghouse
April 77 - Sept 77

March 78 - Nov 78

*NSF-funded

Figure 1-1 Fort Hood Project History 


\subsection{PROJECT ORGANIZATION}

Figure 1-2 depicts the project organization which was in effect during the report period. The Fort Hood project has been a part of the Small Power Systems Frogram directed by DOE's Division of Central Solar Technology. The cognizant field office is the Albuquerque Operations Office (DOE/ALO).

The Aerospace Corporation provides technical support to DOE/ALO, divided into three general task areas: (1) independent. technical analyses, (2) monituring the performance of the prime contractor, and (3) project support activities. No technical direction is given by Aerospace to either the prime contractor or design subcontractor, but access is provided for the exchange of technical information.

The Corps of Engineers has agreed with the Department of Energy to function as Construction Manager for the Fort Hood experiment when the project reaches that stage. Consequently, the Corps of Engineers, through its Fort Worth District Office, supports DOE/ALO in reviewing the system design at each stage. In addition to serving as prime contractor, ATU is responsible for coordinating :site access and interface issues with the Fort Hood Army Command and the Texas Power and Light Company.

\section{3 EXPERIMENT SITE}

As previously mentioned, the 87000 troop housing complex at Fort Hood's Main Post area has been selected for the Solar Total Energy Large Scale Experiment. The general layout of that complex is shown in Figure 1-3: Also indicated in that figure are the five buildings selected to be served by the. experiment with space heating, air conditioning and domestic hot water.

Those five buildings contain $155,560 \mathrm{ft}^{2}$ of floor area. The. three barracks buildings included in the group are of modern three-story construction, as shown in Figure 1-4. The average summer air conditioning load for the five buildings is 51 million $\mathrm{Btu} /$ day and the average winter space heating load is 48 million Btu/day. The electrical demand of the five buildings is an 


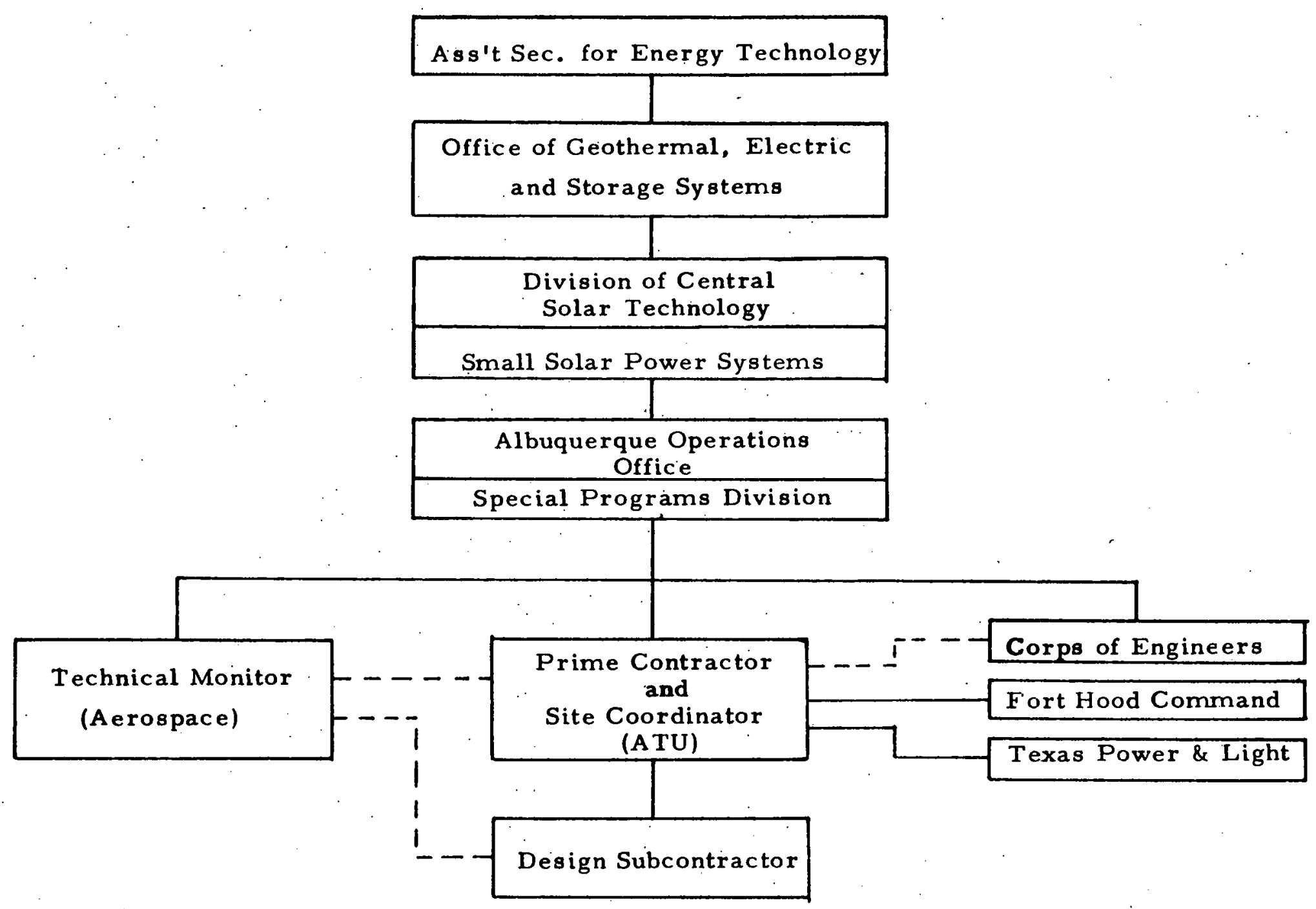

Figure 1-2 Fort Hood Project Organization 


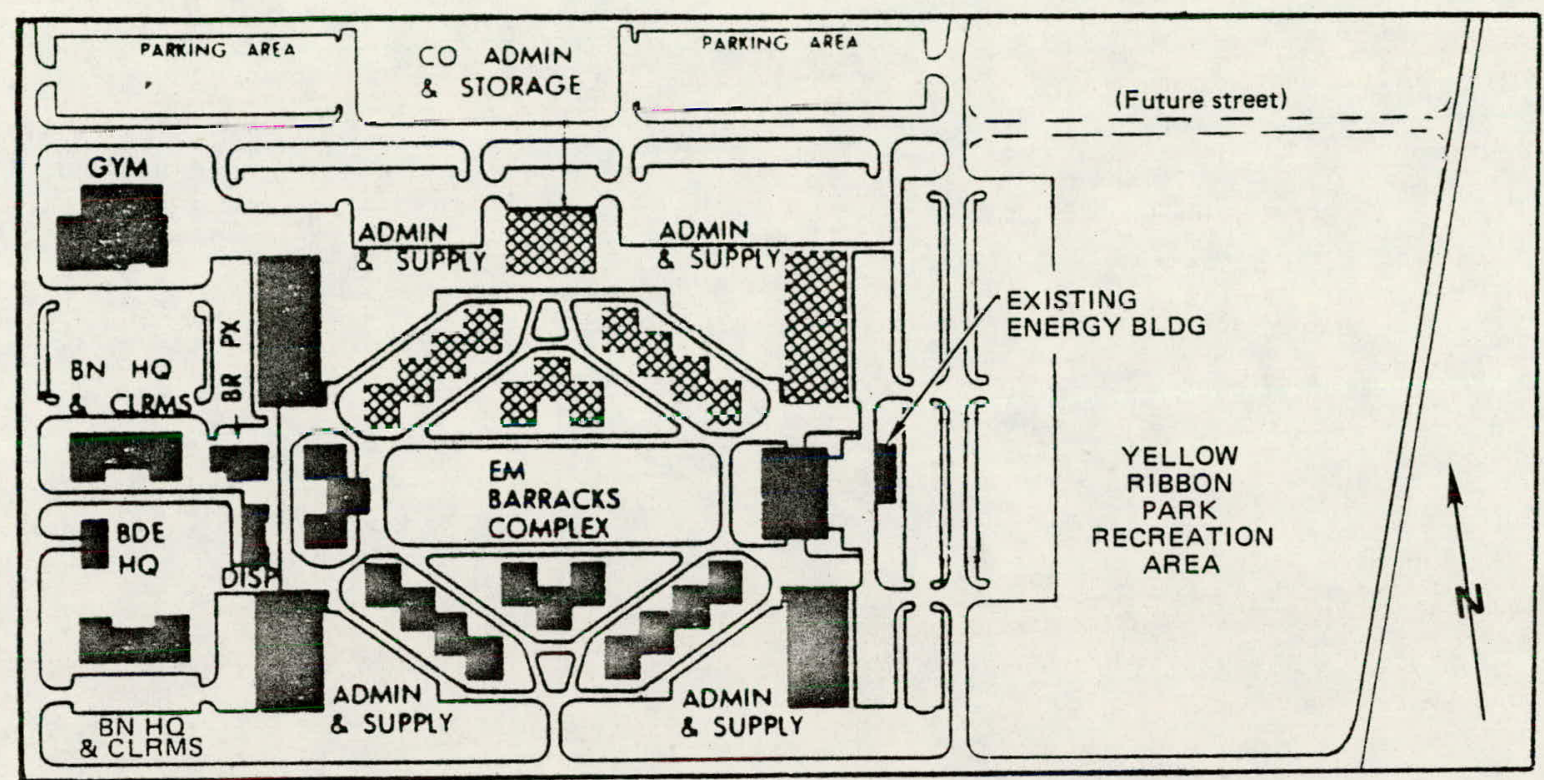

SELECTED BUILDINGS

Figure 1-3 The 87000 Troop Housing Complex

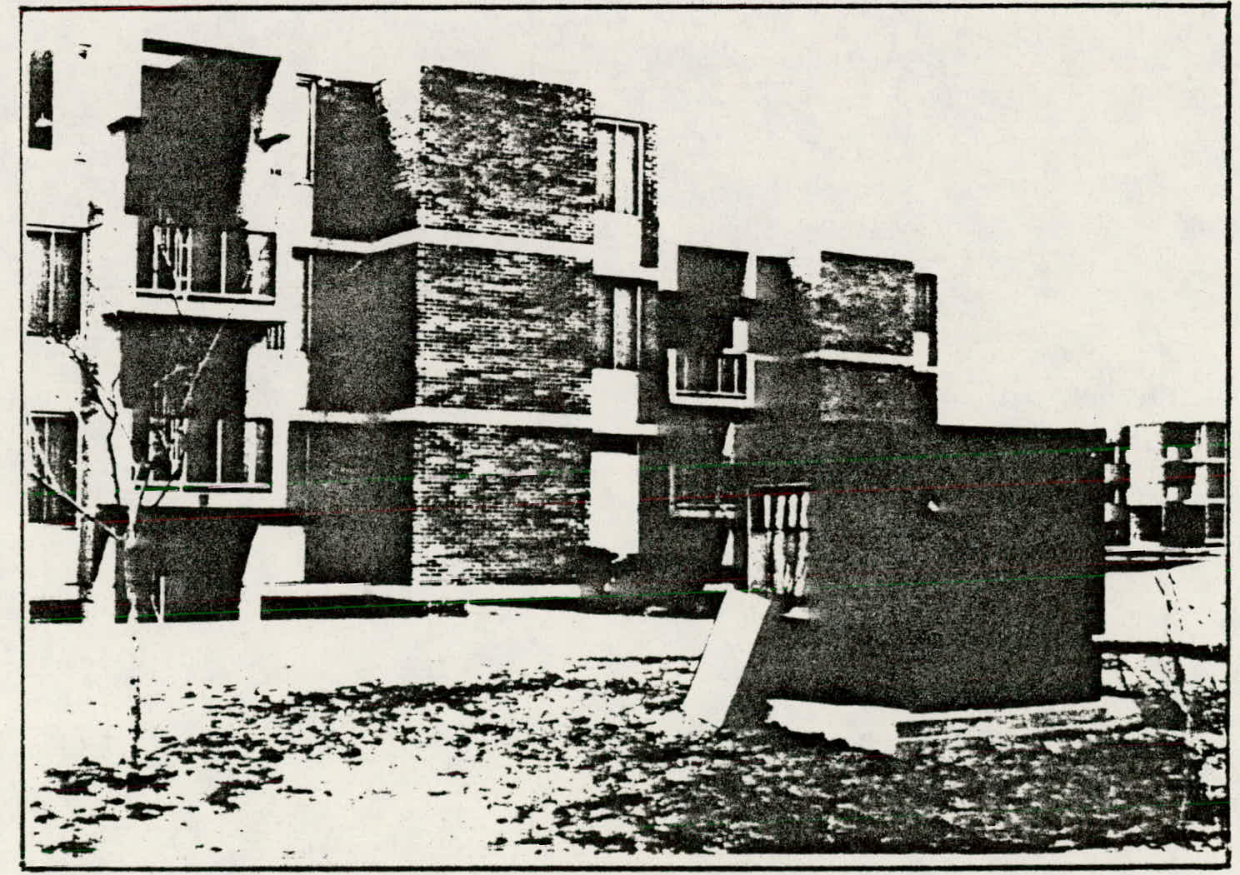

Figure 1-4 Typical Barracks Building 
average of $150 \mathrm{kw}$ with peaks up to $215 \mathrm{kw}$. It is planned that the Solar Total Energy experiment's electrical output not be isolated to those five buildings but rather be fed in a synchronous parallel manner into the general Fort Hood power grid.

Situated on the east side of the selected $\varepsilon$ itc for the experiment is a 13.5 acre parcel of land currently designated as the Yellow Ribbon Recreation Park, which provides an area for a solar collector field capable of supplying enough energy to meet experiment objectives. It is planned that the park and its facilities be relocated in an area. immediatcly south of the complex.

\section{4 EXPERIMENT OBJECTIVES}

The objectives stated by DOE for the Fort Hood Large Scale Experiment are listed in Figure 1-5. The preliminary system design completed in October 1978 was largely consistent with. all the objectives with the solar energy plant achieving an estimated displacement of 57 percent of the annual thermal energy supplied by conventional sources. The restructuring of the project begun during the report period by DOE may eventually result in a revision of the experiment objectives; however, their general meaning is expected to remain unchanged.

2.0 PROJECT REDIRECTION

The special panel convened by DOE/ALO October 17-19, 1978 to review the preliminary design produced during Phase III $B$ concluded that the Fort Hood Solar Total Energy System (STES) as designed could be built and made to accomplish most of the specific objectives of the experiment (R eference 1). However, it was realized that it would be marginal in some respects.

Even though it would fully meet the thermal energy goal (supplying 57 percent versus a 50 percent minimum goal), it would fall short in its electrical output. The DOE guidelines set forth in March 1978 specified an average electrical output of $1600 \mathrm{kwh} /$ day on an annual basis. Though it was not explicitly stated in the guideline, that was assumed to be a net electrical 


\section{EXPERIMENT OBJECTIVES \\ Fort Hood LSE}

Demonstrate all essential elements of a solar total energy system, and collect operations and maintenance data

Conduct experiment of sufficient size to support scaling to larger applications

Use solar energy to displace at least $50 \%$ of the annual thermal energy supplied by conventional sources to the selected buildings

Stimulate large scale manufacturing of solar collector components

Stimulate interest in the industrial sector in solar total energy applications 
production goal. Because of the large parasitic electrical load in components of the STES, the reference system design would deliver to the Fort Hood grid only about five percent of the specified $1600 \mathrm{kwh} /$ day average. With refinements in operating strategy, it was estimated that at most 19 percent of the electricity goal could be supplied.

Consideration of those findings, life cycle cost projections, and the fact that DOE is gaining considerable experience with parabolic trough technology in the Willard, New Mexico and Gila Bend, Arizona solar-powered irrigation projects led DOE to terminate effort on that design since it did not appear to meet the technological objectives of the Small Power Systems Program. It was proposed by DOE Headquarters that the use of a central receiver solar thermal power system be considered for the Fort Hood application.

\subsection{CHANGE IN ENERGY COLLECTION APPROACH}

The change from a parabolic trough solar energy collection system to one using a field of heliostats focusing the sun's energy on an elevated receiver will substantially modify the "front end" of the Fort Hood STES. Downstream of the turbine generator much of the Phase III B design may be usable with minor.changes; the extent to which it is possible is a matter that will require extensive investigation.

A visual comparison of the old and new collector field concepts is provided by Figure $2-1$. The three-subfield parabolic trough subsystem designed by Westinghouse in Phase III $B$ is shown on the left with locations of other major components of the STES indicated. On the right is shown a conceptual layout on the same site of a heliostat/central receiver system. It has been sketched to scale from the design of a small central receiver system sized (Reference 2) to collect $5.97 \times 10^{-6} \mathrm{k}$ wh thermal energy in one year with Albuquerque as a reference location. That is identical to the annual energy collection capability predicted for the parabolic trough system designed for Fort Hood by Westinghouse. However, it is noted that the direct normal insolation may be 


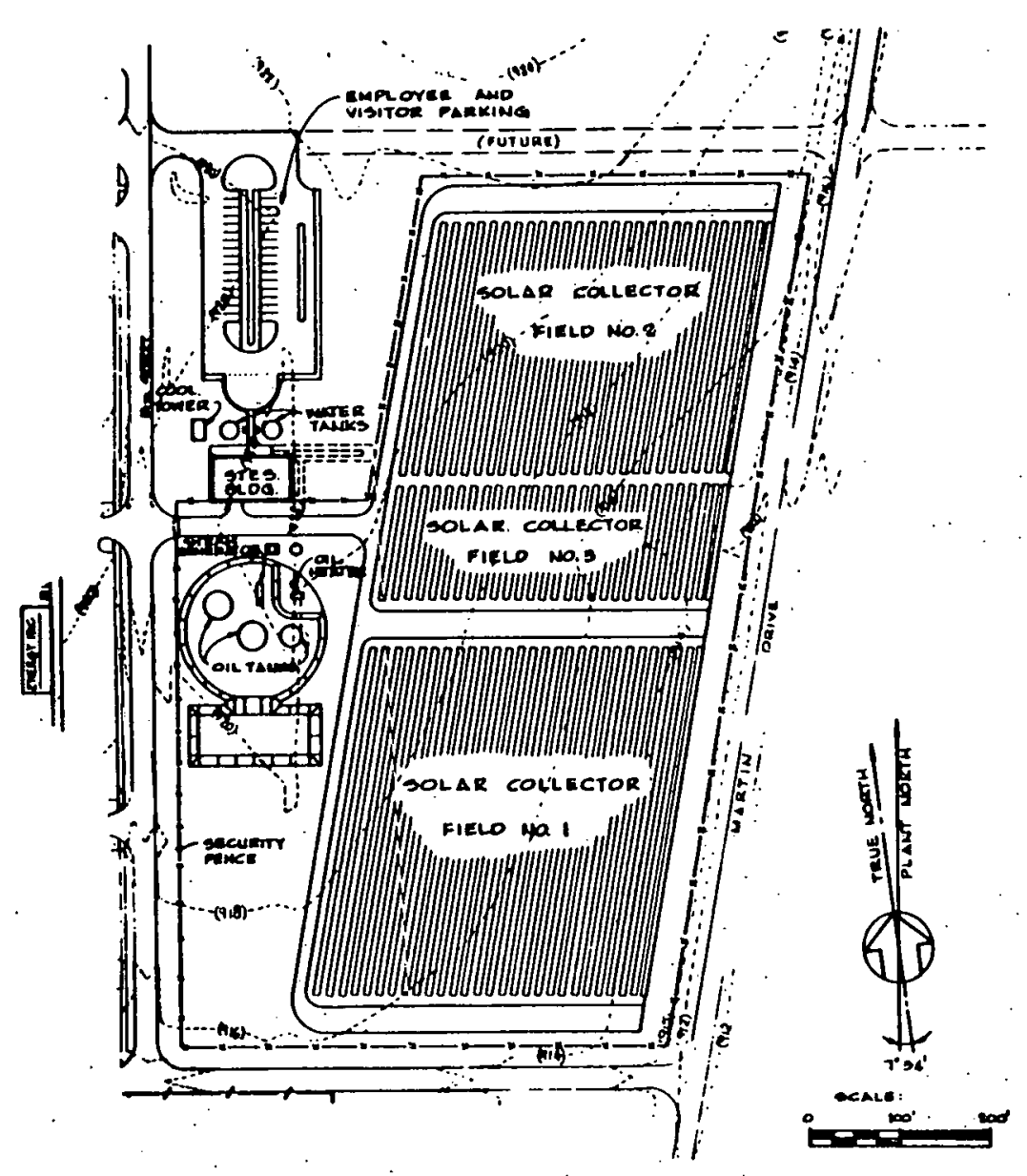

Distributed Line Focus Receiver Concept

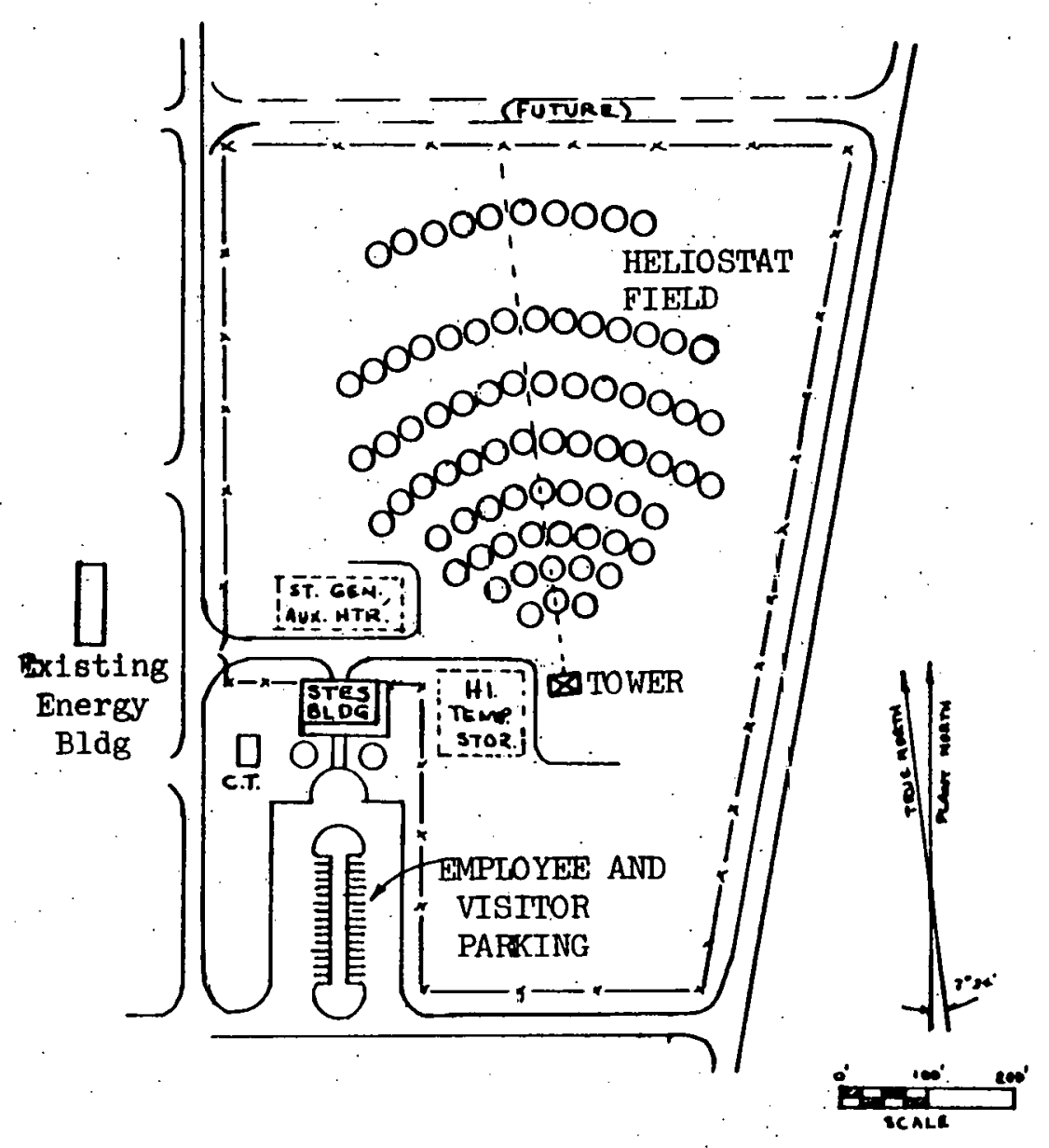

Central Receiver Concept

Figure 2-1 Energy Collection System Concepts for the Fort Hood Experiment 
as much as 30 percent higher at Albuquerque than at Fort Hood (Reference 3 ), so the heliostat field and receiver design from Reference 2 would probably require scaling up in size in order to supply Fort Hood experiment loads.

\subsection{REDISTRIBUTION OF TECHNICAL SUPPORT}

As a result of the decision by DOE Headquarters cited in 2.0 above to stop contracted work on the distributed parabolic trough concept, DOE/ALO directed A erospace to discontinue Task 1 and Task 2 activities related to that design except those deemed necessary to ensure proper completion of the contractor's preliminary design package. That action made it possible to conserve resources during the report period and apply more effort in the Task 3 area to assist DOE in implementing the restructuring of the project. It also made it possible for Aerospace to respond to request from DOE Headquarters, with DOE/ALO concurrence, for technical support to the Shenandoah Solar Total Energy project, analys is of the economic viability of commercial versions of the STES experiments, and technical evaluation of unsolicited proposals.

2. 3 PROCUREMEN T GUIDELINES FOR FUTURE PROJECT PHASES

A Procurement Request (PR) was issued to DOE/ALO by DOE Headquarters in March 1979 for a contract to begin the revised design approach for the Fort Hood experiment.

Accompanying the $P R$ was a set of instructions specifying how future phases of the project are to be structured. It was directed that the contract be set up in phases, divided into segments, with specific review points designated prior to approval for each subsequent phase or segment. The plan is to set up the phases and segments as contract options which can be exercised at the discretion of the Government. The planned sequence of future phases is as follows:

$\begin{array}{lll}\text { Phase III C } & \text { Segment I } & \text { Project Definition } \\ \text { Phase III C } & \text { Segment II } & \text { Preliminary Design } \\ \text { Phase IV } & \text { Segment I } & \text { Definitive Design } \\ \text { Phase IV } & \text { Segment II } & \text { Bid Package Approval } \\ \text { Phase V } & -- & \text { Construction, Test, Checkout } \\ \text { Phase VI } & -- & \text { Operation }\end{array}$


3.0 SUPPORT ACTIVITIES DURING THE PERIOD

3.1 TECHNICAL REVIEW OF PRELIMINARY DESIGN FINAL REPORT

The draft version of the Final Report on the Fort Hood Solar Total Energy Project, Preliminary Design Phase, by ATU, dated October 1978, and the final version of the same report, dated January 1979, were reviewed by Aerospace during the report period with comments being submitted formally to DOE/ALO. There were minor discrepancies between the description of the collector field control scheme presented in the October 12-13 Design Review and that given in the draft. Also, results of the Failure Mode and Transient Response analyses and full specification of number and type of components in the field control system were missing. That was called to the attention of DOE/ALO in the formal evaluation comments, and the missing text was subsequently distributed by ATU to all recipients of the final report.

3. 2 TECHNICAL EVALUATION OF PROPOSALS

Aerospace conducted technical evaluations of unsolicited proposals to DOE from ATU/Westinghouse submitted in December 1978 and from ATU/McDonnell Douglas Astronautics Company, submitted in February 1979. Each proposal described a new design effort to accomplish a conversion of the Phase III $B$ design to one incorporating a central receiver energy collection subsystem in place of the field of parabolic trough collectors. Results of those evaluations were transmitted formally to DOE.

\section{3 ECONOMIC ANALYSES OF STE-LSE DESIGNS}

In February, 1979 Aerospace was directed to conduct an economic comparison of the Shenandoah and Fort Hood 
Solar Total Energy, Large Scale Experiments (STE-LSE) based on life cycle costs. The comparison was to be made for commercial plants which are scaled from the present experiment designs as follows:

a) Scale Fort Hood LSE to $1.5 \mathrm{MW}$ from peak power conditions

b) Scale Shenandoah LSE to $4.0 \mathrm{MWe}$ from peak power conditions

c) Scale Fort Hood LSE to $4.0 \mathrm{MWe}$ from peak power conditions

d) Scale Shenandoah LSE to 1. $5 \mathrm{MWe}$ from peak power conditions

Life rycle cost estimates were to be prepared for the lst and 1000 th plants, and DOE cost goals for collectors were to be used in the analyses.

Difficulties were encountered in performing the analyses in a manner that ensures a fair comparison of the economics of the Fort Hood and Shenandoah experiments because of the widely different applications. The Shenandoah STES design would be required to operate at most some 4100 hours per year, whereas the Fort Hood STES would theoretically operate 8760 hours per year. That is because the Fort Hood application requires STES energy output 24 hours a day, 7 days a week, while the Shenandoah STES is designed to operate only during two standard work shifts at an industrial plant. Insolation would normally be present. during the major portion of one of those work shifts.

Furthermore, in the design of each STES plant, exhaust steam from the turbine generators is utilized to supply thermal energy needs. That makes it difficult to equitably allocate costs to portions of the plants producing thermal and electric energy in order to arrive at the incremental cost of producing each category of energy. 
The overall approach used in the economic comparison is presented in Figure 3-1. The costs of power conversion equipment and all components in the mechanical area were allocated to costs of electrical energy production. Costs of all other subsystems, including the solar collector field, were allocaled to thermal energy production costs. The cost of site subcontracts and indirect costs were distributed. among the subsystem costs according to the fraction of total plant cost represented by each subsystem.

The results of the life cycle cost analyses are shown graphically in Figure 3-2. The 1st plant in each case was assumed to be started up in mid-1981; the 1000th plant in each case was assumed to be started up in mid-2001. It was concluded that DOE cost goals for both trough and dish collectors could be achieved by the year 2000 and that the cost of electricity from either STES would be comparable to Aerospace/Sherman Clark Associates' projections for alternative sources (Reference 4). However, the results are quite dependent on the assumptions used in the study. For example, when calculating the cost of electricity from the Fort Hood STES, credit was given for the electricity consumed in parasitic loads as delivered energy with the rationale that such energy would otherwise have to be purchased for plant operation. If such credit is not given, the cost of electricity produced by the Fort Hood STES becomes considerably higher than that shown.

A subsequent meeting with representatives of DOE, General Electric, Jet Propulsion Laboratories, and Sandia Laboratories to review the Fort Hood and Shenandoah life cycle cost analyses generated the conclusion that a proper economic analysis of the commercialized STES plants should proceed on the basis of determining the total cost of satisfying the design load, rather than on the basis of the cost per unit of either electrical or thermal energy generated. 
- INTERPRET ENERGY PRODUCTION AND LOADS SO AS TO REMOVE OR MINIMIZE INFLUENCE OF APPLICA TION-UNIQUE FACTORS

- assume utility ownership of the solar total energy plant IN EACH CASE WITH THE UTILITY SELLING:

(1) ELECTRICAL ENERGY

(2) THERMAL ENERGY

- INDUSTRIAL PROCESS STEAM

- RESIDENTIAL OR FACTORY SPACE HEATING \& COOLING

- HOT WATER FOR DOMESTIC OR INDUSTRIAL USE

- allocate costs of subsystems, where possible, to the production OF THERMAL OR ELECTRICAL ENERGY SO THAT THE UTILITY-OWNER CAN RECOVER CAPITAL.INVESTMENT BASED ON THE INCREMENTAL COST OF PRODUCING EACH FORM OF ENERGY

Figure 3-1 Overall Approach Used in Economic Comparison of STE-LSE Designs 

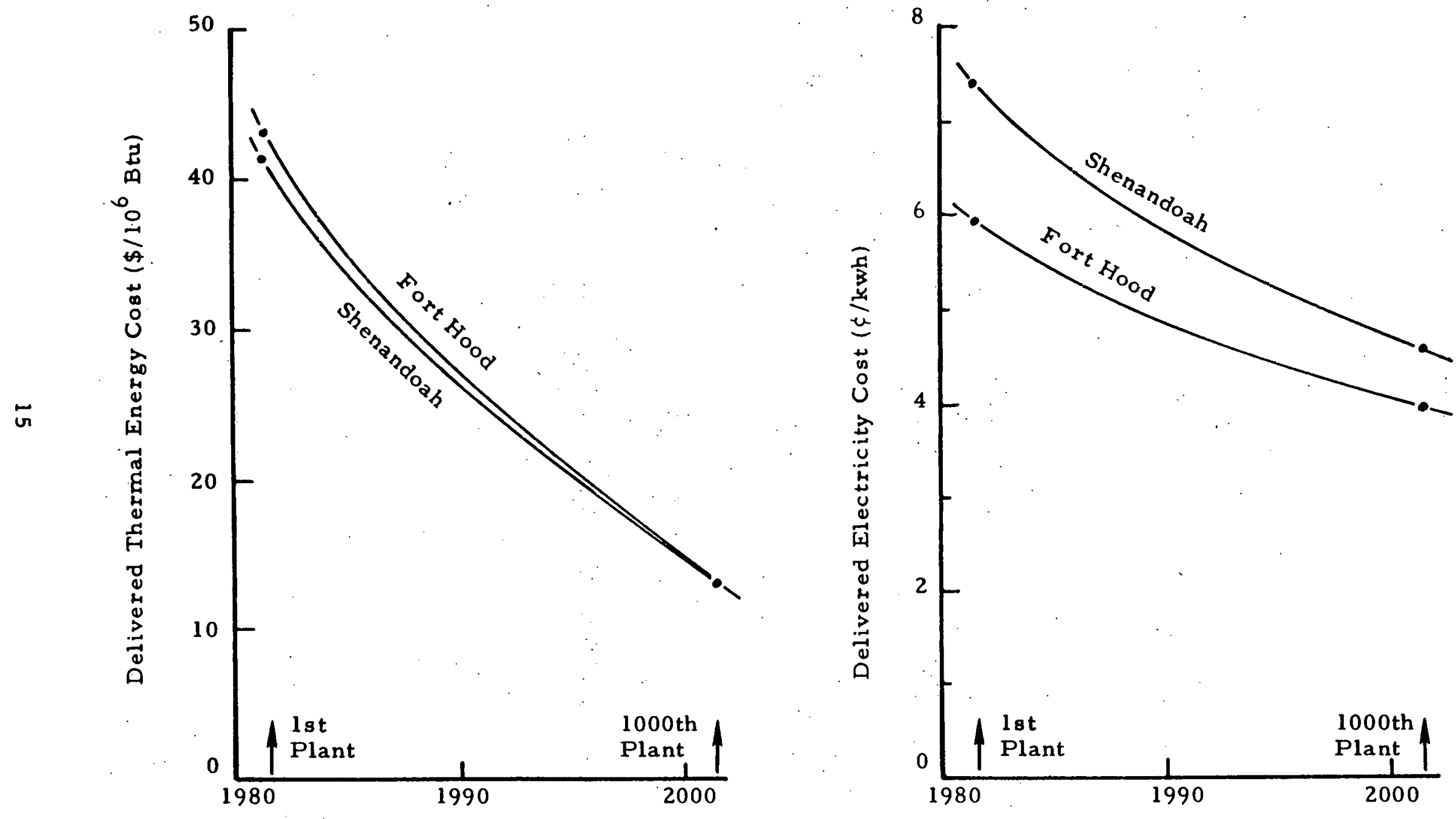

Figure 3-2 Results of Life Cycle Cost Analyses (FY 78 Dollars) 


\section{4 SHENANDOAH PROJECT SUPPORT}

In the period from December 1978 through the remainder of the report period, occasional project support was given by Aerospace to the Shenandoah LSE project. That support was requested by the Small Pnwer Systems Program Office in the Division of Central Solar Technology, DOE Headquarters, and was approved by DOE/ALO.

The support given by Aerospace to the Shenandoah project is typified by the following activities:

a. Supporting Deslgn Reviews conducted by General Electric Company on the project

b. Serving as a member of the Shenandoah Project Review Committee

c. Preparation of vugraphs and other supportive data for internal DOE briefings on the Shenandoah LSE

d. Review and evaluation of the Shenandoah Construction Plan

e. Preparation of a draft Project Plan for the Shenandoah project

\section{5 PROJECT PLANNING ACTIVITIES}

Various tasks of a planning nature were performed to assist DOE/ALO during the report period in the restructuring of the Fort Hood project.

During April documentation was prepared which presented the objectives, schedule, major tasks, project participants; and funding estimates for the Preliminary Design, Definitive Design, and Construction phases of the project. Construction management by the Corps of Engineers was assumed. For purposes of the estimate, a 12-month construction phase was projected beginning in October 1980.

In keeping with the Aerospace recommended project schedule, a critical path network for design and construction tasks was prepared in order to identify long lead procurement items and their possible sources. It was concluded that the fossil-fired heater, steam generator, high temperature storage tanks, low temperature storage tanks, and the demineralizer are long lead items that need to be ordered prior to the start of the construction phase. Other components which may require long lead time 
procurement action are the steel for the tower, the heliostats, and the turbine generator.

It became evident in the critical path network analysis that maximum use should be made of central receiver system technology being developed by the 10 Megawatt Pilot Plant and Experimental System No. 1 projects, and that heliostats for Fort Hood may be obtainable from the 10 Megawatt Pilot Plant production contractor.

A draft version of a Project Management Plan for the restructured Fort Hood project was prepared and submitted to DOE/ALO in May. It was developed according to guidelines in the DOE/ALO "Handbook for ALO Project Development and Management."'

3.6 PREPARATION OF. PHASE III C PROCUREMEN T DOCUMEN TA TION

Following receipt of the PR for Phase III C, Segment I by DOE/ALO, Aerospace prepared a recommended Statement of Work (SOW) for the contractor team of ATU and McDonnell Douglas Astronautics Company (MDAC). Also prepared was a set of attachments to the SOW in keeping with the latest DOE Uniform Contractor Reporting System. A recommended version of the Schedule of Articles to be included in the reinstated ATU contract, consistent with procurement and negotiation instructions in the PR, was prepared and submitted.

Several iterations of the recommended SOW covering both segments of Phase III $C$ were made following coordination with DOE/ALO and DOE Headquarters. A recommended Government Estimate of Phase III C contract costs with detailed manhour allocations by task and estimates in all direct cost categories was prepared in consonance with the latest version of the SOW and submitted to DOE/ALO for assistance in contract negotiations. 
4.0 REFERENCES

1. Fort Hood Solar Total Energy Project, Review of Preliminary Design, The Aerospace Corporation, November 1978.

2. Definition of Two Small Central Receiver Systems, R. J. Holl, McDonnell Douglas Astronautics Company, January 1978 (Sandia Document No. SAND 78-7001).

3. Hourly Insolation and Meteorological Data Bases Including Improved.Direct Insolation Estimates, Final Report, C. M. Randall and M. F. Whitson, Jr., The Aerospace Corporation, 1 December 1977. (Sandia Document No. SAND 78-7047).

4. Solar Thermal Dispersed Power Program, Final. Technical Summary Report, Vol. II, Energy Use and Price Forecasts, The Aerospace Corporation, 31 March 1978. 